\title{
UNITY AND DIVERSITY IN SOCIALIST LAW
}

\author{
JOHN N. HAZARD*
}

I

PRE-Union Soviet LaW

Unity of law was a major casualty of the Russian Revolution. Lenin not only permitted the various ethnic groups which had formed the Russian Empire to secede and create their own legislation; he also made no provision for an appellate tribunal within the new Russian Republic to unify the practice of courts in the various provinces. This was the more remarkable because these courts were authorized to go their own way without regard to centralized guidance. The first decree on the courts ${ }^{1}$ instructed newly created "people's courts" to decide the cases brought before them on the basis of Tsarist legislation, but only to the extent that this had not been specifically revoked and was not contrary to the revolutionary conscience and revolutionary consciousness of the judge.

Common concepts of socialist morality rather than unified legislation became the rock on which the judges were to build. The plan now looks Utopian, but it appeared less so to the communists who were creating the new Russia. To many of them Marxist doctrine was prophetic. It anticipated the ultimate withering away of the state, with its instruments, the courts and the law, as soon as a reorganized economy had produced abundance and a re-educated citizenry had come to understand its social duty. Though no one was prepared to predict, and Lenin even suggested that the process would be rather lengthy, the achievement of communism was expected to come sooner rather than later. A common culture with a common morality was not so far off as to lack reality. ${ }^{2}$

The Commissar of Justice explained the possibilities in a handbook published during the summer of $1918 .{ }^{3}$ In his words, "there appears a new legal consciousness, that is, an internal conviction, first of a few individuals, and later of a group, and then of a whole class, and finally of all mankind." He demanded that this revolutionary legal consciousness become a standard of the people's judges. $\mathrm{He}$ admitted that the process of freeing the judges to decide as their concept of morality required would result in some instability and vacillation of law, but he thought this desirable. Eventually, the highest organs of government could discern a desirable approach and fix it in new laws, but meanwhile improvisation was to be on an individual basis. Even such guide lines as were provided by the old Tsarist legisla-

* Professor of Public Law, Columbia University.

${ }^{1}$ Nov. 2, 1917 (old style), [1917-I918] I Sob. Uzak. RSFSR, No. 2, item I8.

"See Kline, "The Socialist Legality" and Communist Ethics, 8 Naturax L.F. 21 (1963).

${ }^{3}$ P. I. Stuchka, Narodny sud v voprosakh I otvetaka (The People's Court in QUestions and ANSWERS) (MOSCOW, I918). 
tion were removed by the People's Court Act of November 30, $1918,{ }^{4}$ which forbade reference to pre-revolutionary laws. Guides became such legislation as the new government had enacted (very limited and largely pertaining to criminal law) and each judge's socialist concept of justice.

A minimum standard was provided through creation of a "council" of people's court judges to be named by a general meeting of judges in each province or great city, and approved by the provincial government. Its duties were to review records of the courts and to order new trials in the event of substantial violation or incorrect application of decrees, in the event of incomplete investigation, and in the event of clear injustice. Here was the beginning of a form of review to assure uniformity of interpretation not only of statutes but of revolutionary conscience as well. Still, it was not a formal unifying force on a national scale. Not until Lenin found intolerable the variation in application of law from province to province was a national leveller created.

The Commissar of Justice in a January 20 , 1920, circular ${ }^{5}$ complained of lack of uniformity, and he documented his complaint by citation of a considerable number of variations in penalties, as well as approaches to civil law problems. The People's Court Act of October 2I, 1920, ${ }^{6}$ introduced a three line note which was to be the basis for subsequent establishment of a Supreme Court. Yet, it was vague. It provided only that the Commissariat of Justice would have the right of supreme control over criminal sentences and civil decisions of the people's courts and the provincial councils of people's judges. Soon thereafter the Commissariat created a department of court control. ${ }^{7}$ It was this department that began to fill gaps in the legislation, and thus to provide uniformity where the limited number of statutes established no common rule. In the complete absence of a civil code, this became important especially in the civil law field, as when the department established the rights of a bona fide purchaser on the ground that the precision necessary to civil law relationships made it impossible to permit a bona fide purchaser to be deprived of possession simply because the original owner had given a third person a bill of sale. ${ }^{8}$ The department also made choices when there were competing policies between which a trial court could not be expected to choose with any assurance.

While the Russian Republic was developing some unity of law primarily through judicial practice, the governments of other republics created on the ruins of the Russian Empire faced the problem of deciding whether their legislative and judicial policies should be coordinated with those of the Russian Republic. The Belorussian Republic, which was only a fraction of what it became after Soviet acquisition of

- [1917-rg18] I Sob. Uzak. RSFSR, No. 85, item 889.

-Not included in any of the various collections of documents but available only in the original under the title Narodnyi Komissariat Iustitsii, ianvaria 20 dnia 1920g, tsirkuliar No I.

${ }^{\circ}$ [r920] I Sob. Uzak. RSFSR, No. 83, item 407.

'Nov. 26, 1920. Charter of the People's Commissariat of Justice, [1920] I Sob. Uzak. RSFSR, No. 90 , item 465 .

${ }^{8}$ Ezh. Sov. Iust., No. 3 (Jan. 15, I922), p. 10, Case II. 
eastern Poland during the Second World War, seems always to have been close to the Russian Republic and to have copied the work of its leadership. Its judges telegraphed the Russian Republic's Commissar of Justice in December 1918, to praise him for his authorship of the 1918 People's Court Act.' This makes strange reading if one supposed that the two republics were independent of each other. Yet, subsequent events help to clarify the relationship. In i920 the Belorussian Republic's legislature voted to send delegates to meetings of the Russian Republic's legislature and even to unite its administrative ministries with those of the Russians. The governing body of the Azerbaidjan Republic made the same request at that time.

II

\section{UNION AND UNIFICATION, I922-1936}

Formal union was clearly being anticipated by some of the republics well before formal union became a fact through treaty on December 29, rg22. The Russian Republic's Judiciary Act of October $3 \mathrm{I}, \mathrm{I922,}{ }^{10}$ was adopted by the sister republics as their own, although with some delays. Only the draftsmen in the Ukrainian Republic showed signs of some desire to improvise, for they published their draft of a civil code in the summer of 1922 prior to preparation of the Russian Republic's draft. Years later Soviet authors admitted that the Russians had profited from Ukrainian experimentation. ${ }^{11}$ Generally, however, even the Ukrainians were content to follow Russian initiative. As soon as the Ukraine had been cleared with Russian help of invading armies and local opponents, the first decree on courts adopted the Russian formula and declared that "the only source of court activity is revolutionary conscience." The first statute on the court system of February I9, r9I9, ${ }^{12}$ was in the model of the Russian Republic, although not of its first decree. The Ukrainian communists took up the pattern as it stood in the Russian Republic when they came into power. It was not Russia's first decree on the court that they copied, but its third. The Ukrainians jumped over the experiment the Russians had made during the first year with both a people's court for routine cases and a special district court to clear up cases held over from pre-revolutionary times. Generally, thereafter, the Ukrainians followed Russian models, but with some delay and occasional slight variation.

Unification of law was becoming a fact in the various republics that had been created on the territory of the old Empire, but there was no apparent unifying state mechanism. No unification commission issued reports, but there was obviously interchange of documents. When the Ukrainian Commissar of Justice published on August 4, r920, the Russian Republic's circular defining criminal law and establishing what was later to become the general part of the criminal code of 1922 , he made

${ }^{9}$ Prol. rev. i pravo, No. I (II) (January, I9Ig), p. I24.

${ }^{10}$ [1922] I Sob. Uzak. RSFSR, No. 69, item 902.

${ }^{11}$ See N. I. Avdeenko and M. A. Kabakova, Grazhdanskoe prossessul'noe pravo (Civil Procedure Law), published in I 40 Let Sovetskogo Prava (Forty Years of Soviet Law) at 653 n.36 (r957).

${ }^{12}$ [rgrg] I Sob. Uzak. Uk., No. II, item I4I. 
no effort to disguise the origins of his model, for he referred to the Russian circular as his source. ${ }^{13}$

Understanding of this system of unification without formal state machinery requires no elaboration beyond reference to the communist party, and Lenin's plan for reunification of the peoples of what had been the Russian Empire. While Lenin had thought it expedient in I9Iy and I9I8 to permit dissident ethnic minorities to split off from the Russian core so as to permit subsequent reunification of peoples who would have learned the folly of trying to live separately, he permitted no such splits in his communist party. From 1903 he had fought for unity against the Jewish Bund which anticipated a party of individual ethnic units held together by weak federal-type bonds. ${ }^{14}$

Even after the revolution there was pressure for a federal structure within the party, to correspond to the independent states which had come into exixstence within what had been the borders of the Empire. The party at its Eighth Congress in Igrg adopted a resolution rehearsing the state history of separation of ethnic groups, but declaring, "But this does not mean at all that the Russian Communist Party must in its turn be organized on the basis of federation of independent communist parties." The congress decreed: $\mathbf{1 5}^{\mathbf{1 5}}$

There must be a single centralized communist party with a single Central Committee.... The Central Committees of the Ukrainian, Latvian and Lithuanian communists have the same rights as provincial committees of the party and are completely subordinate to the Central Committee of the Russian Communist Party.

With the extra-state mechanism of unity provided by the communist party, Lenin had his instrument for unification of law. The Ukrainian Communists sat as heads of an independent state, but as subordinate members of a communist party over which the Russian party ruled. This principle had its ideological justification in Marx's dictum that the workers knew no fatherland. They were members of a class which cut across state boundaries, and their leadership, the communist party, reflected, therefore, internationalism.

When federation was accomplished on December $29,1922,{ }^{16}$ the treaty of union provided for a federal supreme court. It was to give guiding instructions on the application of federal law; to hear protests brought to it by the federal prosecutor against decisions of republic supreme courts violating federal law; to advise the legislature on republic legislation believed to violate federal law; to decide disputes between the republics; and to try charges of crime levied against federal officials.

${ }^{13}$ [1920] ibid., No. 22, item 438.

14 See Leonard Schapiro, The Communist Party of the Soviet Union 50 (1959).

${ }^{15}$ Resolution on Organizational Questions, Section A, paragraph 5 "National Organizations," I KPSS v Rezoliutsilakh I Reshenitakh S'ezdov, Konferentsil I Pzenumov Tsk (The Communist Party of the Soviet Union in Resolutions and Decisions of Congresses, Conferences, and Plenary Sessions of the Central Committee) 443 (7th ed. I953).

${ }^{16}$ For text of the treaty, see I S'EZD SOVETOV SOIUZA SOVETSKIKH SOTSIALISTICHESKIKH RESPUBLIR (STENOGRAFICHESKII OTCHET S PRILOZHENILAMI) (FIrST CoNGRESS OF THE SOVIETS OF THE UNION OF Soviet Socialist Republics (Stenographic Reports and Annexes)) 8-i I (I923). 
The federal supreme court subsequently absorbed the military and military-transport courts in each of the republics to create a federal system of inferior courts hearing criminal charges related to the very life of the regime. ${ }^{17}$ No inferior federal courts of general jurisdiction were created, however, so that there was no opportunity to develop anything like a federal common law relating to civil disputes and nonpolitical crime, even if the judges had been willing to move in such a direction in violation of the then-current strictures of the Soviet legal system against judgemade law.

Unification of law was to proceed under the first federal constitution with more formality than had been the case when the unified communist party provided the only link between the legislators of the various independent republics created within the confines of what had been the Empire. That the communist party had been successful in its task of providing unity was evidenced by the fact that although the republics entered the union on December 29, 1922, with their own codes of law adopted during the preceding eight months, there was need for very little change as a result of the provisions in the new constitution that general principles of law should be established by the federal state.

These provisions, as incorporated in the first federal constitution, promulgated provisionally on July $6, x 923$, and ratified as the permanent constitution on January $13,1924,{ }^{18}$ declared that the federal state was authorized "to establish principles of judicature and legal procedure as well as principles of civil and criminal legislation for the Union." Authorization also extended to "enact basic labor laws" and to "establish general principles for the development and use of the soil as well as the exploitation of the mineral deposits, forests, and bodies of water throughout the entire territory of the U.S.S.R."

Fundamental principles were established for the judicial system of the republics on October $29,1924,{ }^{19}$ and for criminal law and criminal procedure two days later. ${ }^{20}$ No fundamental laws were adopted until 196r for civil law or civil procedure, but they were established for land use, ${ }^{21}$ and for the collective farm relationships. ${ }^{22}$

III

\section{The Last Three Decades}

\section{A. Stalin's Constitution}

The second federal constitution of December 5, 1936, provided more direct means of unification, for it altered the formula of fundamental principles on the basis of

${ }^{17}$ Oct. 29, 1924, [1924] I Sob. Zak. SSSR, No. 23, item 203.

${ }^{18}$ Art. I, $\$ \$ 0, p$, and $m$. For English translation, see JaMEs H. Meiset \& Edward S. Kozera, Materials for the Study of the Soviet System 153-69 (2d ed. 1953).

${ }^{19}$ [1924] I Sob. Zak. SSSR, No. 23, item 203.

${ }^{20}$ Id., No. 24, item 204.

${ }^{21}$ Dec. 15, 1928, [1928] id., No. 69, item 642.

22 March I, I930, [1930] id., No. 24, item 255, superseded by charter of Feb. 17, 1935, [1935] id., item 82 . 
which republics would enact codes. The new language extended the federal state's jurisdiction to "legislation on judicature and legal procedure; criminal and civil codes." ${ }^{23}$ By amendment in I947 the federal state's authority was further extended to include "establishment of the basic principles of legislation on marriage and the family."24

While the constitutional structure had been altered to facilitate unification, few concrete steps had been taken by Stalin's death. Drafting committees were established and in some fields they had nearly completed their work before the war, but only a Judiciary Act was promulgated. ${ }^{25}$ With the advent of war all further drafting was suspended for the duration, but at its end special drafting commissions were recreated in June and July, I946. Much was done to prepare drafts ${ }^{26}$ but they were kept secret from the general public.

\section{B. The Post-Stalin Era: Decentralization}

Decentralization of controls over the judicial system and legislative authority began after Stalin's death. As a first hint of what was to come the Ministry of Justice of the U.S.S.R. was abolished by decree of May 30, $1956,{ }^{27}$ and the various Republic Ministries were restored to their original authority as guides to the courts and legal institutions within their republics' boundaries. Legislative drafting remained, however, within the federal government, as was still necessary under the constitutional provisions requiring the drafting of federal codes. To do this work which had been, up to that time, the province of the Ministry of Justice of the U.S.S.R., a new "Juridical Commission" was created subordinate to the Council of Ministers of the U.S.S.R. This became the supreme governmental agency for the preparation of laws, but under the constitutional arrangementts its drafts could not be enacted without further consideration. This was the province of the legislative committee of each of the two chambers of the federal legislature, the Supreme Soviet of the U.S.S.R.

\section{Federal Legislation on Fundamentals}

Amendment of the 1936 constitution to restore to the republics the rights established by the first federal constitution followed within nine months of reform of the drafting commission. Article fourteen was amended ${ }^{28}$ to provide that the federal state's authority in the field of judicial structure, criminal and civil law would be limited to the establishing of "fundamentals." The codes themselves would be drafted and enacted by the republics themselves.

${ }^{23}$ Art. I4, $\S u$. For English translation, see MEISEL \& KozERA, op. cit., supra, note I8, at 242-66.

24 Feb. 25, 1947, Ved. Verkh. Sov. SSSR, No. 8 (462), March 6, 1947.

${ }^{25}$ Aug. 16, 1938, id., No. 11, Sept. 5, I938.

${ }^{20}$ See Hazard, Drafting New Soviet Codes of Law, 7 AM. Slavic and East European Rev. 32 (1948).

${ }_{27}$ Izvestiia, June 3, I956.

${ }^{28}$ Id., Feb. 12, 1957. For English translation of constitution in amended form, see JoHN N. HAzARD, The SOWET System of GovernMENT 221-44 (3d ed. I964). 
Draftsmen set to work immediately in the U.S.S.R.'s Council of Minister's Juridical Commission with the help of the legal scholars in the Institute of Law of the Academy of Sciences of the U.S.S.R. and the university professors. ${ }^{20}$ The Institute's director called upon the various departments of his Institute to discuss the subjects to be considered in the new fundamentals, and to bring into the discussion scholars from all of the republics. Proposals and drafts were then exchanged. A guide as to what was considered fundamental already existed in chapter one of the federal constitution, which established the fundmentals of the social structure. Here were found the declarations which were hailed as establishing the socialist character of the U.S.S.R.: the fact that its economic foundation rested on the liquidation of the capitalist system, the abolition of private ownership of the instruments and means of production and the prohibition of hired labor in the productive process except by state agencies.

Some legal detail was provided also by the constitution, for it guaranteed the existence of cooperatively owned property, and also personal ownership of farmhouses, livestock, poultry and minor agricultural instruments as well as of a small garden plot for family use. It also guaranteed the small private economy of peasant artisans, and personal property rights in individual income and savings, articles of household use and personal convenience, and even the right to inherit personal property.

\section{IV}

\section{Federai Fundameentals and Republic Details}

\section{A. A Case Study of Criminal Law}

Criminal procedure was the subject of constitutional concern in a bill of rights requiring that arrest occur only on the sanction of a prosecutor or decision of a court; that homes and correspondence be searched only upon authorization; that all cases be tried with the participation of people's assessors, unless specially excepted

\footnotetext{
29 An author indicates that practice has established the following procedure of coordination between federal and republic draftsmen: The draft prepared by the federal Council of Ministers' Juridical Committee is referred to the legislative committes of the two chambers of the federal Supreme Soviet. These meet in joint session for a preliminary hearing of witnesses and diseussion of principle; a joint drafting committee is appointed for the subject; this joint committee sends a representative to each republic to meet with the legislative committee of the republic Supreme Soviet and its drafting subcommittee; the draft of the federal fundamentals is discussed together with whatever republic draft of a corresponding code may have been prepared, and the two are brought into conformity; the representative returns to Moscow with the drafts of both the fundamentals and the republic code. On the basis of the reports from the fifteen union republics the fundamentals are finally revised, and something of a model republic code is drawn up. This model is returned to the republics for whatever amendments the republics' committees may wish to make without upsetting the unity of legislative principles which is considered a primary characteristic of Soviet legislation. See S. G. Novikov, Postoinnnye KomMissir Verkhovnogo Soveta SSSR (Peraranent Commisstons of the Supreme Soviet of the USSR) 15-2I, 25-29 (Moscow, 1962), and by the same author, Uchastie Nauchnoi Obshchestvennosti $v$ Rabote Komissii Zakonodatel'nykh Predlozhenii Verkhovnogo Soveta SSSR po Podgotovke Zakonoproektov (Participation of the Learned Community in the Work of the Commission for Legislative Drafts of the Supreme Soviet of the USSR in Preparing Drafts of Lauss). [1963] Sov. Gos. I Pravo, No. 12, 56 at $6 \mathrm{I}-64$.
} 
by law; that the accused be provided with interpreters when needed, and with counsel; that trials be in public and that the prosecutor general of the U.S.S.R. have the right to intervene in all cases, whether criminal or civil, if necessary to assure observance of the law.

Beyond these constitutional guarantees the federal government's draftsmen were legally free to choose what they wished to include within the federal fundamentals which they were charged to draft. Subsequent experience showed that there were disagreements, as when the age of responsibility of minors was first left to the republics to establish in their own codes, ${ }^{30}$ but on revision of the draft fundamentals of criminal law by the committees of the Supreme Soviet it was inserted in the federal statute as enacted on December $25,1958^{31}$

Examination of the enacted fundamentals indicates how much unity was to be imposed by the federal state upon the republics. The general provisions of all codes had to be identical in the types of punishment that could be meted out and in the principles to be applied in judging minors, the insane, those acting in self-defense, those who had been accomplices, and those who had not gone farther than preparation or attempt. A uniform period of statutory prescription was set, as were the rules for conditional sentencing and release.

State crimes, military crimes, and crimes directed against the interests of the U.S.S.R. were defined specifically and punishments set. The republics were to be allowed no innovation here. Thus, as a result of the 1958 statutes the federallydefined crimes to be introduced without change into republic codes included: treason, espionage, terrorist acts, diversion, wrecking, anti-soviet agitation and propaganda, warmongering, and conspiracy to commit especially dangerous state crimes. Then followed certain crimes with lesser penalties but great political importance including violation of ethnic and racial equality, disclosure of state secrets, loss of state documents containing state secrets, banditry, smuggling, the stirring up of mass disorders, refusal to do military service, illegal exit from or entrance into the U.S.S.R., violation of transportation safety rules, or damage to means of transportation, counterfeiting, violation of currency regulations, and failure to inform of state crimes.

In contrast to these uniformly defined crimes were the crimes of theft or embezzlement of state or publicly-owned property, damages to such property; murder; manslaughter; mayhem; rape; illegal abortion; sodomy; refusal to pay alimony or maintenance of parents; false imprisonment; failure to give aid to the sick or leaving a person in danger; lying to state officials; insult; denial of electoral rights; forgery of official documents; unauthorized search or reading of correspon-

${ }^{80}$ For the draft, see Sov. Iust., No. 6, at 32-4I (r958).

${ }^{31}$ Art. 10. For the text as adopted on Dec. 25, 1958, see [1959] Ved. Verkh. Sov. SSSR, No. I (1933), item 6. For English translation, see Fundamentals of Soviet Criminal Legiszation, the Judicial System and Criminal Court Procedure, Official Texts and Commentaries (Moscow, I960). 
dence; violation of labor law, or of copyright or patent, or of separation of church and state; as well as property crimes against individuals and economic mismanagement by state officials, speculation, illegal manufacture of spirits, violation of public health regulations, engaging in forbidden business, poaching on state lands, exceeding or failing to use official authority, the giving or receiving of bribes, violation of civil rights by state officials, resisting or threatening state officials, or illegal assumption of authority, and finally, rowdyism and such lesser offenses. All of this latter group was left to the republics to define and to punish as they wished.

Soon after the adoption of the fundamentals of criminal law of 1958 the federal government availed itself of the provision of article two of the fundamentals to enact additional federal criminal law in necessary circumstances. The republics were directed to amend their codes in the interest of uniformity to introduce definitions of crimes for which they had previously, under the 1958 statute, been their own masters. The new definitions related to economic crimes. The change accompanied discovery that considerable numbers of Soviet officials and ordinary citizens were collaborating to steal goods from government stocks for sale on the black market or for their own enjoyment. Bribery had become rampant.

The death penalty was established as a maximum penalty in all republics by decree of May 5, I96r ${ }^{32}$ for theft of property of the state or of public organizations in especially large amounts, as well as crimes not otherwise punishable by death if committed by especially dangerous recidivists and by persons convicted of serious crime and terrorizing at their place of imprisonment, and of attacking or participating in the organization of criminal groups to attack prison guards. The receiving of bribes under most aggravated circumstances, gang rapes, and attacks on the police with intent to kill were defined as federal crimes by decrees in February I962. ${ }^{33}$ The federal statutory definitions were incorporated in the Russian Republic's code by decree of July $25,1962,{ }^{34}$ and by other republics at the same time.

By these emergency decrees the division between federal and republic definition of crime was indicated to rest on evaluation by the leadership of the communist party and by the closely related officials of the federal government of the necessity at any given moment to establish unity of definition and punishment by means more direct that those provided by informal comparison of republic texts and encouragement of common attitudes toward prevention of crime.

The federal decisions of $196 \mathrm{r}$ and $\mathrm{ig} 62$ to expand the list of federally-defined crimes is remarkable in the light of the extensive unification of law which had been achieved in republic codes prior to the expansion. Comparison of the fifteen republic criminal codes demonstrates that all have adhered to a common pattern. Variations

${ }^{82}$ [I96r] Ved. Verkh. Sov. SSSR, No. 19, item 207.

${ }^{33}$ Ibid., [1962] No. 8, items 83,84 and 85 .

${ }^{34}$ [1962] Ved. Verkh. Sov. RSFSR, No. 29, item 449. An English translation by Harold L. Berman of the Russian Republic's code appears as Soviet Statutes and Decisions: A Journal of Translations, Vol. I, No. I (Fall, r964). 
have been introduced in phraseology, in the elements of mitigation and exacerbation, and in penalties, but the general scheme in all shows very little innovation. A look at specific provisions will prove the point. ${ }^{35}$

Take the treatment of the relatively recently defined crime of sodomy. It is much controverted in the West ${ }^{36}$ and might be expected to excite differing treatment in the codes. Before 1933 only one Soviet republic made homosexuality a crime, and then only when it was related to corruption of minors. Joseph Stalin is said to have learned with disgust in 1933 that the practice was spreading in the U.S.S.R., and he responded with a federal decree enacted under the permissive provisions of article three of the 1924 fundamentals of criminal law authorizing federal definition of new crimes "when the U.S.S.R. thinks it necessary to follow a single line through establishment of a single court practice."

Stalin's first decree ${ }^{37}$ limited the definition of homosexual criminality to men, and established two grades: the first, the act in simple form, and the second when it was accomplished by taking advantage of the dependent position of the victim, or if force was used or payment made, or if it was conducted as a profession or publicly. For the first grade, the penalty was to be set at deprivation of liberty for periods up to five years and for the second grade up to eight years. Republics were directed to introduce the crime into their codes but instructed that its introduction was not to require elimination of other articles under which they punished sexual perversion, pimping, seduction and maintenance of brothels.

Within three month $s^{38}$ the federal decree was amended to introduce minimum penalties of three years for the first grade and five years for the second grade of sodomy, and to simplify the definition of the second grade to eliminate reference to payment, professional activity, and public performance. All republics but three incorporated the amended version into their codes. The Ukrainian Republic held to the first version. The Tadzhik Republic retained the I933 definitions but introduced the 1934 minimum punishments. The Uzbek Republic accepted the second version, but retained its rather extensive treatment of homosexuality introduced in 1929 to punish the homosexual corruption of minors and the conduct of schools of homosexual activity.

The 1958 fundamentals changed federal policy to exclude sodomy from the crimes federally defined, and the republics regained their freedom to treat it as they wished. Their new codes ${ }^{39}$ all included it, but introduced considerable variation

\footnotetext{
${ }^{35}$ For the codes, see D. S. Karev (ED.), Ugolovnoe Zaronodatez'stvo SSSR I SoluzNYkH Respublik (Moscow, I957).

${ }^{30}$ See "Catholics and Episcopalians Differ on Law for Sex Deviates," N.Y. Times, Nov, 26, r964, p. $\mathbf{r}$, col. $\mathrm{r}$.

${ }^{37}$ Dec. I7, 1933, [1934] I Sob. Zak. SSSR, No. I, item 5.

${ }^{38}$ March 7, 1934, id., No. I5, item Iro.

${ }^{80}$ The codes of the fifteen republics are published in Ugolovioe Zakonodater'stvo Soruza SSSR I SolUzNykh Respublik (Criminal Legislation of the USSR aNd of the UNion Republics), 2 vols. (Moscow, rg63).
} 
in penalty, and some variation in the description of the exacerbated form. All departed from what had been the precise wording of the 1934 law, although the Russian Republic retained the principal features, and the Belorussian Republic copied its neighbor in every detail. Others innovated. No definition was provided for the first grade, but the title of the crime alone was used in the Kazakh, Lithuanian, Latvian, Kirghiz and Estonian republics. Most republics introduced variety into the definition of the second grade, sometimes to exclude express reference to threats, but to include exacerbating circumstances as a catch-all phrase. Penalties were varied for the first grade from a lower limit of one year to an upper limit varying between two, three and five years, and for the second grade between a lower limit of two and three years to an upper of three, five, seven and eight years respectively, sometimes including exile and banishment.

This review discloses that a crime not prescribed by the federal fundamentals has nevertheless been included in all republic codes, although with varying definition and penalty, presumably related to the special needs of the Great Russian, Ukrainian, Central Asian, and Baltic cultural patterns.

\section{B. Civil Law}

The civil law is likewise treated in a set of federal fundamentals and a civil code promulgated by each republic. The federal fundamentals ${ }^{40}$ establish capacity of citizens and of legal persons, definitions of transactions; agency; a statute of limitations; and conflict-of-laws rules; the definition of property rights in citizens, the state, cooperatives, and public organizations, including the means of protecting ownership provided by the civil law; general provisions on obligations in the various forms usually found in civil codes in Continental Europe, and including what might be called the law of tenancy in the U.S.S.R.; torts; copyright; the law of invention, including patents and author's certificates; and the law of succession.

The republic civil codes add a wealth of detail without which it would be impossible to conduct commercial matters. Thus, the whole law of offer and acceptance is to be found in the civil codes and not in the fundamentals, which in regard to the law of sales are limited to the definition of contracts of sale, the relationship of contract prices to established state planned prices, the liability for improper quality, the statute of limitations on claims, and an article permitting sales on an installment payment plan.

A further example of the extent of unification through the fundamentals may be taken from the law of succession. In five articles, the fundamentals state the general principle that there may be inheritance by law and by will, and define the

${ }^{\circ}$ Dec. 8, I96x, effective May I, 1962. [196r], Ved. Verkh. Sov. SSSR, No. 50 (1085), item 525. English translation in Soviet Civil Legislation and Procedure-Officiar Texts and Commentaries (Moscow, n.d.). 
first two categories of heirs by operation of law. The provision on wills lists the general principle of complete freedom to bequeath as the testator desires, mitigated by the prohibition to exclude certain categories of heirs completely. The final articles establish the liability of an heir for the debts of the decedent and the place of administration of the estate. The civil code of the Russian Republic treats the same subject in thirty-five articles providing the formalities required of a valid will, the right to alter wills before death, the acceptance or rejection of inheritances, notification to heirs, escheat, the rights of creditors against an estate, the naming of guardians, and the issuance of certificates of inheritance, and special rules relating to inheritance of the undivided property of a collective farm household.

Comparison of the law of sales as treated by four republics in the civil codes adopted in 1963 and 1964 in implementation of the fundamentals of $196 \mathrm{I}$ suggests that the rule is to be uniformity rather than wide diversity. ${ }^{41}$ In this important commercial field which concerns not only individuals but public corporations engaged in implementing the state economic plan through contracts, much crossing of republic frontiers by shipments can be anticipated. Chapter three of the Russian, Ukrainian, Latvian and Kazakh civil codes treats the matter generally in development of the fundamentals. The result is conformity, with little variation, to some master model which must have been circulated, for the treatment is provided in articles placed in the same order, and even with close similarity of phraseology. Even such a matter as the age of capacity to contract is identical in all, although much has been made in the past in family law of differences in the rate of maturity of children in the various republics. In the detailed treatment of offer and acceptance and the form of a contract, which are not mentioned at all in the fundamentals, the same rules have been established by the republics in chapters which vary in number from fourteen to sixteen, but which are of a single verbal pattern.

The law of inheritance as it appears in the republic codes shows no greater variation, although this is a field which lacks stimulation toward unity comparable to the stimulation established for the law of sales by interrepublic commerce. The variation between codes is again only verbal. An example is provided by treatment of the responsibility of an heir for the debts of a decedent. In the Russian and Kazalk civil codes the obligation is stated only with regard to "an heir." The Ukrainian and Latvian codes add a paragraph to cover a multiple-heir situation in which they declare that liability for debts extends only in proportion to the share of the estate received. Likewise, all but the Ukrainian code provide specifically for the extinction of a creditor's right against the estate if not presented within six months after opening of the estate to claims. The Ukrainian civil code establishes the obligation to file within six months, but is silent as to consequences of failure to conform.

\footnotetext{
"Each civil code has been published separately, the Ukrainian in Kiev in 1964, the Kazalh in Alma Ata in 1964 , the Latvian in Riga in 1964 , and the Russian in Sov. Iust., No. 13-14 (1964).
} 
Unification of LaW in the Communist World

Unification of law between the republics of the U.S.S.R. and the socialist states beyond Soviet boundaries is hampered by the obvious barriers created by state frontiers, but there was a considerable measure of unification in spite of the barriers until Tito's expulsion from the Communist Information Bureau in 1948. At that time a process was set in motion to which no one can yet see the end, but it is evident that the ties that formerly bound in the absence of federal relationships no longer have strong force. Clearly, this weakening of fraternal bonds has been a surprise to the Soviet leadership which gave signs after the war of expecting the various new Socialist states guided by communist parties to follow as quickly as economic and social conditions permitted the steps taken by the various republics within the boundaries of the old Russian Empire.

\section{A. An Early Precedent: Outer Mongolia}

Proof of the early expectations of Soviet leaders is offered by the history of the Mongolian People's Republic. Its communist leaders established a People's Government on July II, Ig2I, and immediately nationalized primary resources, with the exception of cattle herds. Since Outer Mongolia was a nomadic society without industry, the new measures made little impression upon the population, but they laid the base for subsequent emulation of the Soviet system. Mongolia also modernized the penal law with the help of a Russian adviser. ${ }^{42}$ The first constitution of November 26, 1924 , was patterned after that of the Russian Republic of rg18. When the U.S.S.R. adopted its constitution of 1936 , the Mongolian People's Republic followed the pattern in a second constitution of June 30 , 1940. ${ }^{43}$ Its specialized decrees were similar to, but not identical with, those of the republics of the U.S.S.R. Thus the law on land use of February 6, r942, established the Soviet formula of state ownership of land, accompanied by allocation of use in perpetuity to the herdsmen for their privately owned cattle. A Labor Law of February i4, 194I, and a social insurance law of June 22, I942, followed the Soviet pattern.

\section{B. The Post-War "People's Democracies"}

No other territory came under the domination of communists until after World War II, but with the advance of Soviet armies into Eastern Europe and Asia in pursuit of treating German and Japanese forces, the situation changed. In each country, as it was cleared of Axis troops, there emerged general social and economic patterns similar to those of the U.S.S.R., with such variation as seemed to be related

${ }^{42}$ Ginsburgs \& Pierce, Revolutionary Lay Reform in Outer Mongolia, 7 LAw IN EAsTERN EUROPE 207 (1963).

${ }^{4}$ Hazard, The Constitution of the Mongol People's Republic and Soviet Inftucnces, 21 Pacipic AFFAIRS I62 (1948). 
to the degree of economic development achieved by the state at the time it came under communist domination. Generally, capitalists (with the exception of landlords) were permitted to own productive property in Eastern Europe and China, and law had to reflect the presence of capitalists as it had in the U.S.S.R. during the period of the New Economic Policy. ${ }^{44}$

In spite of the absence of formal ties, the People's Democracies have all nationalized banks, large scale industry, insurance, mining, and transport, so that the Soviet model in what was called the socialized sector of the economy was followed closely. Even the form of administration of state industry was copied from Soviet experience, so that the state was represented by a manager who was given full powers as a "one-man manager," and his enterprise was created in the form of a public corporation functioning upon a cost accounting basis known by the Russian word "khozraschet."

The class bias of law was stated similarly in each of the new People's Democracies, as was the role of legal institutions. Thus, the Hungarian People's Republic in its constitution of August 20, 1949, declared "Courts of the Hungarian People's Republic punish enemies of the working people, defend and secure the state, economic and social structure of the people's democracy, its offices and the rights of the toilers, educate the toilers in the spirit of observance of the rules of socialist intercourse." Civil rights were limited in the constitutions as they had been in that of the U.S.S.R. Thus the Bulgarian communists in their constitution of December 4, I947, granted the right to form associations, but only "if they are not directed against state and public order established by the present constitution." It then added in the spirit of the successive Soviet constitutions drafted for Lenin and Stalin, "It is forbidden and will be punished by law to form organizations having as their purpose taking from the Bulgarian people the rights and freedoms won by the people's uprising of September 9, I944. . . ."

The law to be applied by the courts was determined in much the same way as had been the case in the Russian Republic before codification in I922. Thus, Poland at first speedily unified its legal system essentially along pre-war lines but later subjected it to the IIg articles of a General Statute on Civil Law, of July I8, I950. The draftsmen sought to avoid harm to the working class in application of the "old" law by providing in article three, "It is forbidden to use one's rights to violate the fundamentals of socialist intercourse of the people's government."

In each of the People's Democracies Soviet tutors sat at the side of the men preparing the laws to give technical advice. Some were present primarily as experts in government organization, and without specifying models that had to be fol-

" Constitutions and basic laws in Russian translation were published between 1950 and I956 in a series of volumes entitled Zakonodater'stvo Stran Narodnor DemokratiI, KonstitutsiI I Osnovinye Zaronodatel'nye Akty (Legislation of Countries of People's Democracy. Constitutions and Basic Legislattve Acts) (Moscow). 
lowed, they offered suggestions from their own experience which were eagerly seized upon by the new administrators, some of whom had been trained in universities of the U.S.S.R. Chiefs of the various communist parties had themselves received indoctrination in fundamentals in Moscow prior to or during the war, so that their political orientation corresponded to that of their teachers.

For some years after the war it looked as if the People's Democracies were being groomed to enter the U.S.S.R. in fulfillment of the promise of the representative of the Communist International in $x 922$ shouted at the conclusion of the congress uniting the various republics of the U.S.S.R. He had indicated the expectation of many when he cried, "Long live the U.S.S.R. of the world!" Under this concept Poland, Rumania, and the others were being moved to a status within the Soviet federation.

\section{Tito's Separate Course}

Dreams of federation of all People's Democracies in the U.S.S.R. were dashed by Tito of Yugoslavia in early 1948. His refusal to accept Stalin's timetable for collectivization of agriculture and guidance in many other sectors resulted in announcement of expulsion of his party from the Cominform on June $28,1948 .^{40}$ Before expulsion his constitution of January 3r, 1946, had followed the Soviet pattern. Even after expulsion, he continued to foster Stalin's model of monopoly of political power in a communist party and the necessity of withholding large productive resources from private ownership, but he began experimentation with public participation in political affairs and industrial control. Finally, he developed the concept of the Socialist Alliance to unite wide segments of the politically faithful, and "social ownership" under which workmen in a plant are brought into the management process so that they may share with the local governing unit in the selection and dismissal of the plant manager. Tito returned the farmland to individual households except in the most productive areas, and reprieved the individual artisans. Most importantly, he sent home his Soviet advisers and declared himself independent of Moscow's guidance.

\section{VI}

\section{Deveiopments Since the Twentieth Party Congress}

Other People's Democracies showed signs of restlessness, but not until October, I956, three years after Stalin's death, and after denunciation of his methods in the 2oth communist party congress of the Soviet Union, did the revolt break into the open. The Hungarians moved swiftly in open defiance, forcing the Soviet leadership to stamp out the rebellion with troops. The Poles moved more cautiously, and gained their point after a stormy session with Stalin's heirs-and with what has

${ }^{45}$ See G. W. Hoffman \& F. W. Neat, Yugostavia and the New Comaunism 135-38 (1962). 
been interpreted as the support of the Chinese who were also beginning to feel the desire for independence of action.

\section{A. China}

Since October 1956 , the communist-led states have engaged in a variety of legislative actions deviating from the Soviet model. The most noted of these deviations has been that of the Chinese. In spite of a constitution of September 20, I954, ${ }^{46}$ establishing with finality a system of courts patterned on those of the U.S.S.R., and having, therefore, a professional judge and two lay assessors supported by prosecutors organized on the Soviet model, and in spite of creation of a law codification commission in the spring of r950, the Chinese ceased to proceed as had been expected. At some point in the late 1950s, they gave up the plan to codify, and purged judges as "rightists" in 1957 when the latter espoused many of the principles which were being made the basis of Soviet criminal procedure by Stalin's heirs, notably "socialist humanism."

The conflict between Soviet and Chinese views of the nature of law in a communist-led state reached its height in the summer of 1964 , when the Soviet communist party's propaganda chief told a gathering of Soviet authors: ${ }^{\mathbf{4 7}}$

The present-day splitters are also revising in theory and in practice Lenin's directives on the need for the strictest observance of socialist legality. To this day in China there are actually no codes at all: neither a code of criminal procedure, nor a civil code, nor a code of civil procedure. Moreover, attempts are actually made in Chinese juridical literature to justify violations of the law theoretically. Socialist law is regarded chiefly as an instrument of suppression: its creative constructive role is ignored. Thus, the Chinese press asserts that articles of the law "possess definite elasticity and they may be called a rubber measure."

Unification of law between China and the U.S.S.R. is out of the question when there is such a conflict of views as to the social role of law and the relationship between state and individual. Chinese scholars are reported to be working on a treatise on law, but returning European travelers report that it will require at least two more years for completion. The outside observer might think it possible for a reconciliation of viewpoints to be based on acceptance by the Chinese of the argument that they are far behind the U.S.S.R. in economic and social development and therefore require preservation of the elasticity of law evidenced in the U.S.S.R. before the codifications of 1922 occurred. Yet this has not happened.

Some evidence that the argument of similar but delayed development along Soviet lines was gaining ground in China can be found before the Khrushchev-Mao quarrel broke sharply into the open in I963. Let us look, for instance, at the

${ }^{6}$ For English translation, see Albert P. Blaustein, Fundamental Legal Documents of Communist China I-33 (1962).

"See "Ilychev speech indicts Chinese social sciences," I6 Current Digest of the Soviet Press, No. 35 , at $8, \mathrm{I}_{4}$ (Sept. $23, \mathrm{xg}_{4}$ ). 
similarity in principles of criminal law as they have emerged in China since 1949. ${ }^{48}$ The emphasis upon class, upon applications of law by "analogy," and on educational measures of rehabilitation rather than punishment present many points of similarity with what was said in the U.S.S.R. before Stalin's death. Yet, since 1957 there has been sharp divergency. Criminals who commit serious crimes or show no evidence of reform in repeated offenses are called class enemies even though springing from worker or peasant stock. Soviet humanistic attitudes are denounced as bourgeois and subjective, and Soviet procedural guarantees for the accused are given no reflection in Chinese procedure. ${ }^{49}$

\section{B. Eastern Europe}

The Eastern European People's Democracies have been quite different in their approach. Instead of cutting loose from Soviet models and moving toward flexibility like their Chinese comrades, they have been slipping from the harness to move toward greater predictability. They have wanted more stability in law rather than less. They have moved to maintain procedural guarantees such as the presumption of innocence, when the U.S.S.R. has refused to permit its statement in express words. They have espoused humanism in western terms and refused to accept sacrifice of the individual for the mass with the same willingness as the Russians. They have sought to maintain their identities as heirs of western European culture. They have not relished the heritage of Byzantium which they associate with their comrades in the U.S.S.R. They have been communists, but communists with a difference.

Their codes reflect the general patterns of thought current in the communist fatherland, but they have been developed with none of the close adherence to a Moscow-fostered model which is to be found among the republics of the U.S.S.R.

Take the same problem which was examined within the criminal codes of the Soviet republics, namely sodomy. ${ }^{50}$ There is wide variation. Some of the People's Democracies establish no such crime, these being Rumania, Albania, and Bulgariaunless the latter's article 159 punishing compulsion of another to commit or consent to commit something against his will can be regarded as a basis for prosecution of the exacerbated form punished in the Soviet codes, as might also be Albania's article 160 which punishes sexual relations established with use of force, threat or by virtue of the helpless condition of the victim.

The Hungarian and Czechoslovak criminal codes punish homosexuality between

${ }^{48}$ See Fu-shun Lin, Communist China's Emerging Fundamentals of Criminal Laı, 13 AM. J. CoMp. L. $80\left(\mathrm{Ig}_{4}\right)$.

${ }^{10}$ The contrast between Chinese and Soviet attitudes toward criminal law and procedure are reviewed in Hazard, Le Droit pénal soviétique et l'Etat du peuple tout entier, [1964] REvUE DE SCIENCE Criminelle et de Droit Penal Comparé (nouvelle série) 294-305.

${ }^{50}$ Russian translation of the codes of the European People's Democracies were published in Moscow in $196 \mathrm{I}$ and 1962 in a pocket series entitled Ugolovnoz Zakonodatel'stvo ZarubezhynYKII SotsialisticheskikH Gosudarstv (Criminal Legislation of the Foreign Socialist Countries). 
women as well as men, although the Soviet codes do not, but the Hungarian code punishes the act only if compelled or achieved by virtue of the helpless condition of the victim. Penalties are higher if the victim is a minor. Yugoslavia punishes the act between men but only with penalties up to one year, unless force or threat of direct bodily harm is used, when the maximum penalty is ten years. ${ }^{51}$ The German Democratic Republic adheres to the old German code of I87r, and, therefore, punishes unnatural relations between men with a prison term and deprivation of the rights of a citizen, and increases the penalties if the victim is a minor or if force is used or if it is conducted as a business. Penalties may be reduced to three months imprisonment if circumstances are of a mitigating character.

Comparison of civil codes among the Eastern European People's Democracies indicates that they generally conform to their European antecedents, as do those of the U.S.S.R., except for Czechoslovakia, which in Ig64 promulgated a document with several innovations. Its law of contracts is defined as a law of "services" for many relationships. This means that form contracts from which there may be no departure are introduced for such services, and only a few details are left to the will of the parties. Further, contracts are no longer classified as in the various Soviet codes according to the purpose to be achieved, such as sale, exchange of goods, gift, supply, state procurement, loan, secured loan, lease, commission, construction, shipment, insurance, agency, storage, and offering of prizes in competition. The Czechoslovak code classifies according to the parties concerned. Thus, four categories are established: (I) agreements made in foreign trade; (2) those having to do with transactions of socialized organizations in implementing the economic plan; (3) those between socialized organizations and private citizens; and (4) those between private citizens.

This change in system of classification means that the Czechoslovak draftsmen have departed from the unity which the Soviet specialists have prized highly and defended against attack from those among their own number who had argued after Stalin's death that there should be a division between the law relating to public corporations and the law relating to citizens, since in their view, the public corporations required a law that would be far more flexible than that required in the relationships between citizens.

The Czechoslovaks have also invented a new type of contract in the fourth group. It is called "civil assistance," and concerns the performance of work for a neighbor or a loan to him to help him out. No exact parallel is found in the Soviet codes. As a rule this civil assistance must be given free, and if it takes the form of a loan, it must bear no interest unless specifically agreed upon and not exceeding a legal limit. When performed, such assistance must conform to the principles of socialist intercourse.

51 The Yugoslay government has published an English translation under the title Criminal Code (Union of Jurists' Associations, Belgrade, 1960). 


\section{Intra-Bloc Collaboration in Legal Matters}

From what has been indicated, unification among the communist-led states has been conceived more as a unification of legislative aim than as a unification of texts. The communist leaders of the People's Democracies, in spite of their differences and their desire to escape dictation by the Soviet Union's communist party, have continued to think of their legal systems as related in political orientation to each other. Variations there will be, but not so great as to necessitate the building of a legal wall preventing enforcement of each others' criminal and civil sentences and judgments. The relationship is seen as wholly different from that existing within the states which lie outside the communist-led circle.

The difference in attitude between communist partners and between communist states and those considered bourgeois is given concrete illustration by Soviet treaty practice. No treaties of judicial assistance have been concluded by the U.S.S.R. with any non-communist-led states, while a series of bilateral treaties has been concluded with both Asian and European communist-led states. ${ }^{52}$ Under these treaties the U.S.S.R. and its treaty partners agree-in the words of, e.g., the treaty of August 3I, 1957, between the U.S.S.R. and the Czechoslovak Republic-to recognize the enforceability of any decision in matters of civil or family law and also of organs of guardianship, as well as civil judgments made in connection with a criminal prosecution to the benefit of the victim. Extradition of criminals is also agreed upon, if under the law of both states the penalty may exceed one year's deprivation of freedom. Conflict-of-laws principles are also established by these treaties.

On January 1, 1958, commercial relations between the European communist-led states were brought under a set of obligatory rules applicable to inter-state sales transactions, so that uniformity may be assured in treatment without regard to the civil codes of the states concerned. ${ }^{53}$ In this way, commerce between the European communist-led states is subjected to uniform rules, and Czechoslovakia or any other such state may experiment with new forms of civil law without upsetting transnational relations. ${ }^{54}$

\footnotetext{
52 The treaties are collected in Dogovory oB OKAzANII PRAvovor POMOSHCH po GrazHDANSKIM SEMEINYM I UGOLOVNYM DELAM, ZAKLIUCHENNYE SOVETSKIM SOIUZOM V 1957-1958GG (AGREEMENTS on Judicial Assistance in Civil, Famizy, and Criminal Matters Concluded by the Soviet UNION IN I957-58) (Moscow, 1959). The many other forms of establishing cooperation are fully described in $\mathrm{K}$. Grzybowski, The Socialist Commonwenlth of Natrons-Organizations AND INSTITUtions ( 1964 ).

53 The text of the General Conditions of Delivery of Goods between Forcign Trade Organizations of Member-Countries of the Council of Mutual Economic Aid, adopted in 1958, has been translated by Harold J. Berman and published in 7 INT'L AND COMP. L.Q. 665-90 (1958). His information led him to conclude that its provision of clauses to be inserted in foreign trade contracts was not obligatory on members of the COMECON. Later Victor Chikhvadze in a communication to the New York (1964) Colloquium of the International Association of Legal Science declared that the provisions were obligatory.

54 The 1958 rules replaced the $195 \mathrm{I}$ rules and 28 separate bilateral agreements previously concluded under the $195 \mathrm{I}$ terms. The Asian communist-led states are still related to the U.S.S.R.
} 
Even commercial relations with capitalist states fall under a unifying influence in the various communist-led states because their civil codes establish rules relating to choice of law which designate the legal system of the communist-led state as governing unless specific provision is made to the contrary, and such specific provision is hard to negotiate. Further, all communist-led states maintain within their foreign trade establishment an arbitration tribunal under their sole control. Foreign trade contract partners are urged to accept jurisdiction of these tribunals in arbitration clauses. This puts the law of the communist-led state before a tribunal of the same state for interpretation, and there is thus little likelihood of variation in application of the law.

Soviet commercial policy experts evidence confidence in their arrangements and the unlikelihood of hostile foreign decisions requiring enforcement in communistled states, for the U.S.S.R. has ratified the European Convention on the enforcement of arbitral awards signed in Geneva on June 2r, $196 \mathrm{I}^{.55}$

\section{Conclusion}

In conclusion, the communist-led states, with the exception of the Chinese People's Republic, have moved toward a unity of concept which has made for considerable unification of socialist law. Codes of the republics of the U.S.S.R. vary in only slight degree and appear to have been drafted on a common model even in those sections not regulated specifically by federal law. As between the People's Democracies of Europe and the U.S.S.R. there is greater variation, but a common approach has been preserved. Since acceptance by Soviet communist leaders of the fact of resistance, evidenced by Tito's disaffection and the 1956 events in Hungary and Poland, there has been less pressure from the Soviet side for conformity to Soviet models in textual detail. For the moment, at least, such pressures are out of the question because the reaction to Soviet domination has been great since the death of Stalin. Policy makers in the communist-led states are showing a desire for independence, and especially so in Asia. The Chinese variation is extreme since the Chinese have no codes at all.

Perhaps at some future time, if the common culture which Soviet leaders have sought to achieve as their goal is approached, the law of the communist-led states will become textually unified, but that moment seems remote, in spite of repetition of the goal in the Program of I96I adopted by the Communist Party of the Soviet Union. It would probably coincide with the moment when the state should wither away, and law would become a system of morals without enforce-

in commercial dealings through bilateral agreements. See Luntz, Problems of Private International Law in the Relations Between the Countries of the World Socialist System, SOvIET YEARBOok ON INTERNATIONAL LAW, I959, at 82 (I960).

${ }^{t 5}\left[x_{964}\right]$ Ved. Verkh. Sov. SSSR, No. 44 (I235), item 485 . 
ment by state institutions. Unification would then be not of laws but of morals. The very statement of the possibility invites incredulity among those who work in legal fields in the West, but it seems to be a myth that gives courage to those in the communist-led states to carry on, and like all myths, it may have influence upon future policy direction. 